\title{
Effects of various lighting regimens and pinealectomy on semen production in Romney rams
}

\author{
G. K. Barrell* and K. R. Lapwood \\ Department of Physiology and Anatomy, Massey University, Palmerston North, New Zealand
}

\begin{abstract}
Summary. Sixteen Romney rams were utilized in a $2 \times 2$ factorial experiment designed to evaluate the effects on semen production of (i) contrasting lighting regimens, and (ii) pinealectomy or sham-operation.

Reversal of the annual photoperiodic cycle advanced the seasonal peak of fructose levels in semen by 4 months and also reduced percentages of unstained and morphologically normal spermatozoa. Pinealectomy abolished this advancement of peak fructose production and reduced overall concentrations and motility of spermatozoa. Moreover, towards the end of the study pinealectomized rams had higher ejaculate volumes than did sham-operated rams.

Testicular and accessory sex gland data obtained after the rams were killed showed a marked influence of the lighting regimen: high values from sham-operated rams in short daily photoperiods contrasted with depressed values from those in long daily photoperiods. Pinealectomized rams provided values midway between these extremes, a finding which suggested both anti- and pro-gonadotrophic roles for the pineal gland in rams.
\end{abstract}

\section{Introduction}

Seasonal changes in semen production and plasma hormone levels in Romney rams in New Zealand have been described in a previous paper (Barrell \& Lapwood, 1979a). Since the factor considered to be primarily responsible for such changes is the length of the daily photoperiod (Marshall, 1937; Ortavant, Mauléon \& Thibault, 1964), seasonality of reproduction is usually studied by placing sheep in light-controlled environments. The role of the natural annual photoperiodic cycle has been investigated by comparing semen production of rams exposed to contrasting phases of the cycle, i.e. phase reversal/non-reversal experiments (Fowler, 1961; Moule, Braden \& Mattner, 1966). Other workers have used 'shortened-phase' experiments in which the annual photoperiodic cycle has been compressed into 6 months (Colas, Laszczka, Brice \& Ortavant, 1972; Jackson \& Williams, 1973). Jackson \& Williams (1973) demonstrated that Suffolk rams subjected to such lighting regimens experienced similar cyclic changes in some semen characteristics.

Evidence from rodent research has shown that the pineal gland mediates photoperiodic effects on reproductive activity and has led to the view that this gland may have an important controlling influence in all seasonally breeding animals (Reiter, 1974). With respect to sheep this theory was not supported by the results of Roche, Karsch, Foster, Takagi \& Dziuk (1970) who were unable to show any effects of pinealectomy on the incidence of oestrus or ovulation in ewes. However, a significant relationship between pineal gland activity in ewes and stage of the oestrous cycle has been reported (Cardinali, Nagle \& Rosner, 1974). Also Barrell \& Lapwood (1979b) recorded altered seasonal patterns of $\mathrm{LH}$ and prolactin secretion as well as changed

* Present address: Department of Veterinary Science, Lincoln College, Canterbury, New Zealand. 
ejaculate sperm concentrations from cranial cervical ganglionectomized rams; it was claimed that ganglionectomy produced its effects by modifying pineal gland activity.

In the present study Romney rams were subjected to two lighting regimens to examine photoperiodic influences on semen production. Furthermore, pinealectomized rams were included to ascertain the role of pineal activity in regard to ovine reproduction. Results of plasma LH, testosterone and prolactin measurements have been reported elsewhere (Barrell \& Lapwood, 1979c).

\section{Materials and Methods}

Adult Romney rams were housed in well-ventilated light-proof rooms maintained at a constant temperature of $15^{\circ} \mathrm{C}$. Each ram was kept in an individual crate and fed chaffed meadow hay (approximately $1400 \mathrm{~g}$ ) and sheep nuts (approximately $650 \mathrm{~g}$ ) every morning at about 09:00 $\mathrm{h}$. Water was always available.

Lighting, provided by two 80-W fluorescent lights so that a light intensity of approximately 110 lux was received at eye-level by the rams, was controlled by automatic time-switches which were adjusted once per week to produce the required changes in daily photoperiod. Lighting regimens, based on data from the New Zealand Nautical Almanac (1972), were: normal (normal seasonal changes in photoperiod) and reversed (reversed seasonal changes in photoperiod). In both regimens daily photoperiod varied in a sinusoidal manner from $9 \mathrm{~h} 20 \mathrm{~min}$ minimum to $14 \mathrm{~h} 40$ min maximum.

Rams were pinealectomized as described by Roche \& Dziuk (1969), or sham-operated by an identical procedure except that, after exposure, the pineal glands were left in situ. Surgery was carried out between 1 and 6 weeks before the start of the experiment, by which time all rams had recovered from the operations and were in good health. Post-mortem macroscopic and histological examinations of brains from all rams were carried out after the experiment and confirmed the effectiveness of both surgical procedures. Four pinealectomized and 4 shamoperated rams were allocated at random to each lighting regimen and the experiment lasted from the September 1974 equinox until the end of the following May.

Semen was collected by electro-ejaculation every 2 weeks and appraised for ejaculate volume, motility index, percentage of motile spermatozoa, concentration of spermatozoa per $\mathrm{ml}$, number of spermatozoa per ejaculate, fructose concentration and content, fructose concentration of seminal plasma, and percentages of unstained and morphologically normal spermatozoa, as described previously (Barrell \& Lapwood, 1979a). Semen data were pooled to give 8 , approximately monthly, means for each parameter. For statistical analysis the time course of the experiment was divided at the December solstice so that the first 3-monthly means comprised Period 1 and the final 5 monthly means comprised Period 2. This enabled between-treatment comparisons to be made for Period 2 when gonadal functions in rams normally are stimulated by decreasing photoperiods (Ortavant et al., 1964). Orthogonal coefficients (from Fisher \& Yates, 1963) were utilized in the analysis of variance to partition changes in semen parameters during the time course of the experiment.

At the completion of the study all rams were anaesthetized with intravenous pentobarbitone sodium. Immediately afterwards the head of each ram was perfused, first with isotonic saline, then with a $10 \%(\mathrm{v} / \mathrm{v})$ formalin $-0.9 \%(\mathrm{w} / \mathrm{v}) \mathrm{NaCl}$ solution to fix the brain tissue. Subsequently the brains and pituitary glands were removed for histological processing and weighing, respectively. Testes, epididymides, seminal vesicles, ampullae and thyroid glands were removed and weighed, and the seminiferous tubule diameters, epididymal sperm reserves, and seminal vesicular fructose contents and concentrations were determined as described previously (Barrell \& Lapwood, 1979b). Effects of lighting regimens, operations and their interaction on these parameters were examined by analysis of covariance with body weight as the covariate. 
Significance levels for important contrasts in the statistical analyses are shown in the tables of results.

\section{Results}

Few overall time-related changes were recorded for the semen parameters measured during this experiment (Table 1). Significant increases in mean values were obtained for ejaculate volumes, percentages of unstained spermatozoa and seminal fructose levels (Text-fig. 1). Conversely a decline in values was recorded for the percentage of motile spermatozoa. Values for other semen parameters showed no particular time-related trends.

Rams subjected to the reversed lighting regimen produced ejaculates with lower percentages of motile, unstained and morphologically normal spermatozoa than did rams kept in normal lighting. Reversed lighting also brought forward the peak of fructose output in the semen; seminal fructose levels in the rams in normal lighting were still increasing at the end of the study but peaked during February and were declining during the last 3 months in the rams in reversed lighting (Text-fig. 1). However this effect of reversed lighting on seminal fructose production was

Table 1. Data (mean \pm s.e.m.) for ejaculates collected from sham-operated (Control) and pinealectomized (PinX) rams subjected to normal or reversed lighting regimens

\begin{tabular}{|c|c|c|c|c|c|c|}
\hline \multirow[b]{2}{*}{ Semen parameter } & \multirow[b]{2}{*}{ Period $\dagger$} & \multicolumn{2}{|c|}{ Normal lighting } & \multicolumn{2}{|c|}{ Reversed lighting } & \multirow{2}{*}{$\begin{array}{c}\text { Variance ratio } \\
\text { significance levels }\end{array}$} \\
\hline & & Control & Pin $X$ & Control & Pin $X$ & \\
\hline Volume (ml) & $\begin{array}{l}1 \\
2\end{array}$ & $\begin{array}{l}1.21 \pm 0.12 \\
1.10 \pm 0.08\end{array}$ & $\begin{array}{l}1.15 \pm 0.06 \\
2.04 \pm 0.17\end{array}$ & $\begin{array}{l}1.26 \pm 0.16 \\
1.54 \pm 0.18\end{array}$ & $\begin{array}{l}1.29 \pm 0.09 \\
1.80 \pm 0.10\end{array}$ & $\mathrm{~b}^{* *} ; \mathrm{c}^{* * *} ; \mathrm{d}^{* *}$ \\
\hline $\begin{array}{l}\text { Spermatozoa } \\
\quad \text { Motility (scale 0-4) }\end{array}$ & $\begin{array}{l}1 \\
2\end{array}$ & $\begin{array}{l}3 \cdot 0 \pm 0 \cdot 1 \\
3 \cdot 0 \pm 0 \cdot 2\end{array}$ & $\begin{array}{l}2.9 \pm 0.1 \\
3.0 \pm 0.1\end{array}$ & $\begin{array}{l}3 \cdot 1 \pm 0 \cdot 1 \\
2 \cdot 8 \pm 0 \cdot 1\end{array}$ & $\begin{array}{l}2.9 \pm 0.1 \\
2 \cdot 3 \pm 0.1\end{array}$ & $b^{*}$ \\
\hline$\%$ Motile & $\begin{array}{l}1 \\
2\end{array}$ & $\begin{array}{l}60 \cdot 9 \pm 1 \cdot 6 \\
58 \cdot 4 \pm 3 \cdot 0\end{array}$ & $\begin{array}{l}57.9 \pm 1.5 \\
55.8 \pm 1.3\end{array}$ & $\begin{array}{l}62 \cdot 4 \pm 2 \cdot 1 \\
54 \cdot 8 \pm 2 \cdot 3\end{array}$ & $\begin{array}{l}56 \cdot 3 \pm 2 \cdot 3 \\
44 \cdot 2 \pm 2 \cdot 0\end{array}$ & $a^{*} ; b^{* *} ; c^{* *} ; d^{*}$ \\
\hline \% Unstained & $\begin{array}{l}1 \\
2\end{array}$ & $\begin{array}{l}65 \cdot 5 \pm 1 \cdot 5 \\
72 \cdot 3 \pm 2 \cdot 6\end{array}$ & $\begin{array}{l}65 \cdot 0 \pm 3.9 \\
76 \cdot 6 \pm 1 \cdot 3\end{array}$ & $\begin{array}{l}60 \cdot 3 \pm 4 \cdot 2 \\
64 \cdot 9 \pm 1 \cdot 5\end{array}$ & $\begin{array}{l}58 \cdot 3 \pm 0 \cdot 8 \\
67 \cdot 8 \pm 2 \cdot 0\end{array}$ & $\mathrm{a}^{* * *} ; \mathrm{c}^{* * *}$ \\
\hline $\begin{array}{l}\text { \% Normal } \\
\text { morphology }\end{array}$ & $\begin{array}{l}1 \\
2\end{array}$ & $\begin{array}{l}77 \cdot 5 \pm 2 \cdot 5 \\
78 \cdot 3 \pm 1 \cdot 1\end{array}$ & $\begin{array}{l}73 \cdot 3 \pm 2 \cdot 3 \\
69 \cdot 9 \pm 2 \cdot 9\end{array}$ & $\begin{array}{l}70.8 \pm 0.9 \\
70 \cdot 2 \pm 1.1\end{array}$ & $\begin{array}{l}74 \cdot 3 \pm 2 \cdot 0 \\
67 \cdot 1 \pm 2 \cdot 0\end{array}$ & $\mathrm{a}^{*}$ \\
\hline No. $/ \mathrm{ml}\left(\times 10^{9}\right)$ & $\begin{array}{l}1 \\
2\end{array}$ & $\begin{array}{l}3.51 \pm 0.16 \\
2 \cdot 83 \pm 0.20\end{array}$ & $\begin{array}{l}2.92 \pm 0.17 \\
3.17 \pm 0.21\end{array}$ & $\begin{array}{l}4.12 \pm 0.53 \\
3.88 \pm 0.32\end{array}$ & $\begin{array}{l}3.03 \pm 0.17 \\
2.59 \pm 0.23\end{array}$ & $\mathrm{~b}^{* *} ; \mathrm{e}^{* *}$ \\
\hline $\begin{array}{l}\text { No./ejaculate } \\
\left(\times 10^{9}\right)\end{array}$ & $\begin{array}{l}1 \\
2\end{array}$ & $\begin{array}{l}4.88 \pm 0.67 \\
3.78 \pm 0.13\end{array}$ & $\begin{array}{l}3.54 \pm 0.51 \\
6.89 \pm 0.70\end{array}$ & $\begin{array}{l}5.34 \pm 1.18 \\
6 \cdot 69 \pm 1.26\end{array}$ & $\begin{array}{l}4.23 \pm 0.38 \\
4.92 \pm 0.36\end{array}$ & $\mathrm{e}^{* *}$ \\
\hline $\begin{array}{l}\text { Fructose conc. } \\
\qquad(\mathrm{mg} / \mathrm{ml})\end{array}$ & $\begin{array}{l}1 \\
2\end{array}$ & $\begin{array}{l}0.61 \pm 0.13 \\
2.65 \pm 0.83\end{array}$ & $\begin{array}{l}0.86 \pm 0.10 \\
2.58 \pm 0.60\end{array}$ & $\begin{array}{l}0.75 \pm 0.32 \\
2.22 \pm 0.41\end{array}$ & $\begin{array}{l}0.98 \pm 0.12 \\
3.26 \pm 0.62\end{array}$ & $c^{* * *} ; d^{* * *}$ \\
\hline $\begin{array}{l}\text { Total fructose content } \\
\text { (mg) }\end{array}$ & $\begin{array}{l}1 \\
2\end{array}$ & $\begin{array}{l}0.75 \pm 0.09 \\
3.83 \pm 1.30\end{array}$ & $\begin{array}{l}0.95 \pm 0.11 \\
5.75 \pm 1.59\end{array}$ & $\begin{array}{l}1.38 \pm 0.91 \\
4.18 \pm 0.83\end{array}$ & $\begin{array}{l}1.29 \pm 0.24 \\
6.00 \pm 1.41\end{array}$ & $\mathrm{c}^{* * *} ; \mathrm{d}^{* *}$ \\
\hline $\begin{array}{l}\text { Seminal plasma } \\
\text { fructose conc. } \\
\text { (mg/ml) }\end{array}$ & $\begin{array}{l}1 \\
2\end{array}$ & $\begin{array}{l}0.80 \pm 0 \cdot 18 \\
3 \cdot 15 \pm 0.94\end{array}$ & $\begin{array}{l}1.09 \pm 0.14 \\
3.22 \pm 0.70\end{array}$ & $\begin{array}{l}0.90 \pm 0.41 \\
2.78 \pm 0.51\end{array}$ & $\begin{array}{l}1.16 \pm 0.15 \\
3.74 \pm 0.70\end{array}$ & $\mathrm{c}^{* * *} ; \mathrm{d}^{* *}$ \\
\hline
\end{tabular}

Values are for 8 rams/group. Data were calculated from 7 observations/ram in Period 1 and 10 observations/ ram in Period 2.

$\uparrow$ Period 1, September to December 1974; Period 2, January to May 1975.

$\S$ Contrasts: a, normal versus reversed lighting.

b, sham-operated versus pinealectomized.

c, Period 1 versus Period 2.

d, Period 2-parameters increased with time (except decrease for \% motile spermatozoa).

e, 'lighting regimens $x$ operation' interaction.

${ }^{*} P<0.05$; $^{* *} P<0.01$; ${ }^{* * *} P<0.001$. 


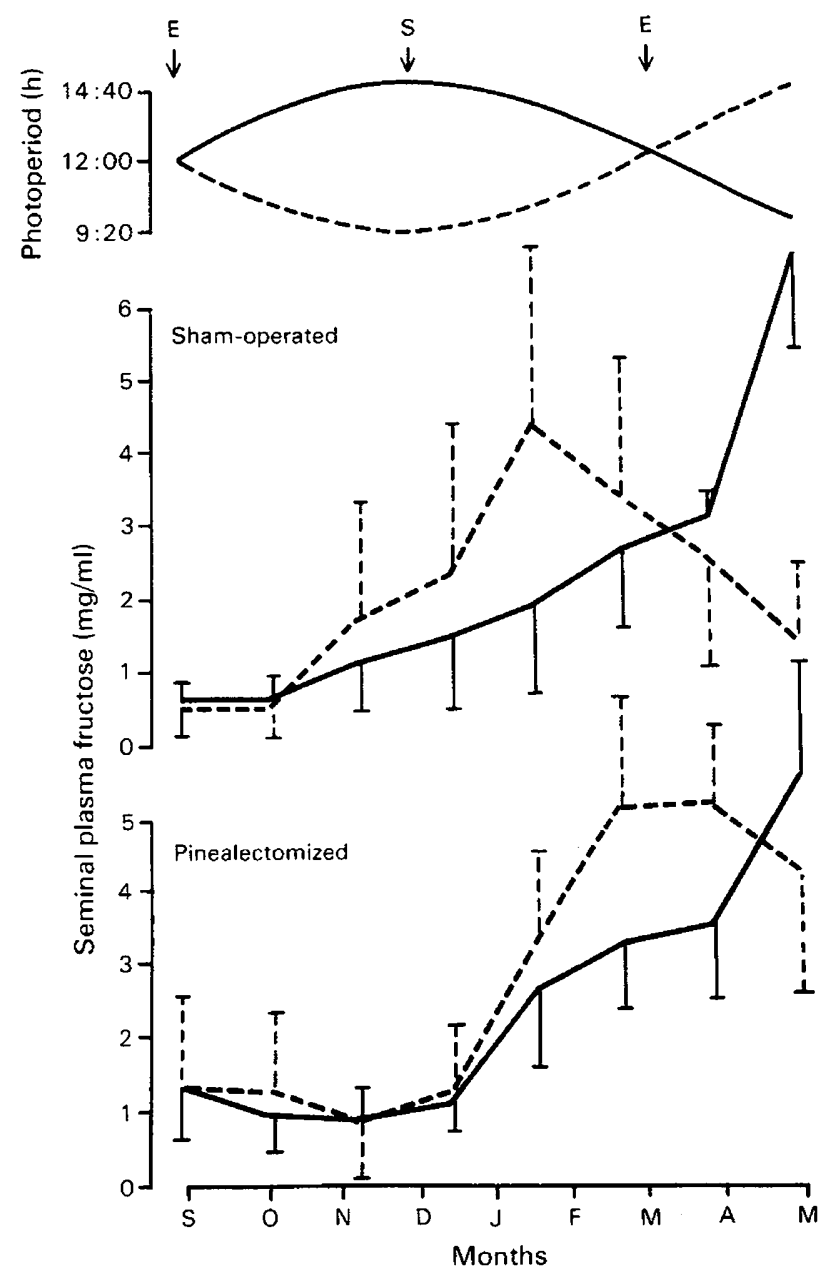

Text-fig. 1. Monthly changes in mean seminal plasma fructose concentrations in ejaculates from sham-operated or pinealectomized rams subjected to normal $(-)$ or reversed $(--\infty)$ lighting regimens. Daily photoperiod changes are illustrated together with the timing of the equinoxes $(E)$ and the solstice (S). Each point represents the mean of 2 fortnightly ejaculates from each of 8 rams.

confined to sham-operated rams and was not recorded from pinealectomized rams on the same lighting regimen $(P<0.05)$.

Pinealectomy elevated mean \pm s.e.m. ejaculate volumes $(1.65 \pm 0.11$ versus $1.32 \pm 0.08$ $\mathrm{ml}$ ) but lowered indices of sperm motility $(2.7 \pm 0.1$ versus $3.0 \pm 0.1$, scale $0-4)$, percentages of motile spermatozoa $(52.6 \pm 1.7$ versus $58.5 \pm 1.4)$ and concentrations of spermatozoa in semen $\left(2.91 \pm 0.12\right.$ versus $\left.3.53 \pm 0.19 \times 10^{9} / \mathrm{ml}\right)$.

Data collected following slaughter of the rams showed some marked influences of the lighting regimens. Compared with the rams kept in reversed lighting, those under normal lighting had higher mean values for: testicular weight, epididymal weight, epididymal sperm reserves, seminal vesicular weight, fructose content and fructose concentration (Table 2). However, the highest and lowest mean values for these parameters were obtained from sham-operated rams under normal and reversed lighting, respectively, and the pinealectomized rams had mean values intermediate between those two extremes. This effect of pinealectomy was indicated by the 
Table 2. Data (mean \pm s.e.m.) obtained at autopsy from sham-operated (Control) and pinealectomized (PinX) rams subjected to normal or reversed lighting regimens (8/group)

\begin{tabular}{|c|c|c|c|c|c|}
\hline \multirow[b]{2}{*}{ Parameter } & \multicolumn{2}{|c|}{ Normal lighting } & \multicolumn{2}{|c|}{ Reversed lighting } & \multirow{2}{*}{$\begin{array}{l}\text { Variance ratio } \\
\text { significance levels } \dagger\end{array}$} \\
\hline & Control & $\operatorname{Pin} X$ & Control & $\operatorname{Pin} X$ & \\
\hline Body weight $(\mathrm{kg})$ & $75 \cdot 3 \pm 1 \cdot 8$ & $80 \cdot 1 \pm 3.9$ & $75 \cdot 9 \pm 2 \cdot 1$ & $81 \cdot 4 \pm 2.5$ & \\
\hline Testicular weight (g) & $429 \cdot 6 \pm 20 \cdot 1$ & $417.5 \pm 50.3$ & $238 \cdot 7 \pm 35 \cdot 1$ & $337 \pm 31.6$ & $a^{* * *}$ \\
\hline $\begin{array}{l}\text { Seminiferous tubule diam. } \\
(\mu \mathrm{m})\end{array}$ & $207 \cdot 1 \pm 4 \cdot 3$ & $204 \cdot 2 \pm 7 \cdot 7$ & $188.4 \pm 7.0$ & $204 \cdot 6 \pm 2 \cdot 3$ & \\
\hline Epididymal weight (g) & $84 \cdot 7 \pm 5.9$ & $70 \cdot 2 \pm 5 \cdot 7$ & $45 \cdot 6 \pm 2 \cdot 6$ & $59 \cdot 1 \pm 3 \cdot 3$ & $a^{* * *} ; b^{* *}$ \\
\hline $\begin{array}{l}\text { Epididymal sperm } \\
\text { reserves }\left(\times 10^{9}\right)\end{array}$ & $101 \cdot 4 \pm 6 \cdot 2$ & $74 \cdot 8 \pm 5 \cdot 6$ & $31 \cdot 5 \pm 6 \cdot 0$ & $50.4 \pm 13 \cdot 6$ & $a^{* * *} ; b^{*}$ \\
\hline Ampullary weight (g) & $5.48 \pm 0.48$ & $4.54 \pm 0.63$ & $3.96 \pm 0.12$ & $4.26 \pm 0.32$ & \\
\hline Seminal vesicle weight $(\mathrm{g})$ & $15 \cdot 6 \pm 2 \cdot 2$ & $8 \cdot 1 \pm 1.4$ & $6.5 \pm 0.8$ & $9 \cdot 6 \pm 0.4$ & $a^{*} ; b^{* *}$ \\
\hline $\begin{array}{l}\text { Seminal vesicle fructose } \\
\text { content (mg) }\end{array}$ & $81 \cdot 8 \pm 15 \cdot 4$ & $35.4 \pm 8 \cdot 7$ & $9 \cdot 0 \pm 1 \cdot 7$ & $32 \cdot 3 \pm 7 \cdot 3$ & $a^{* *} ; b^{* *}$ \\
\hline $\begin{array}{l}\text { Seminal vesicle fructose } \\
\text { conc. }(\mathrm{mg} / \mathrm{g})\end{array}$ & $510 \cdot 8 \pm 35 \cdot 2$ & $545 \cdot 7 \pm 151 \cdot 8$ & $174 \cdot 9 \pm 28 \cdot 9$ & $334.4 \pm 67 \cdot 0$ & $a^{* *}$ \\
\hline Pituitary weight (mg) & $1049 \pm 137$ & $1426 \pm 165$ & $1197 \pm 91$ & $1238 \pm 206$ & \\
\hline Thyroid weight (g) & $9 \cdot 1 \pm 0.4$ & $10 \cdot 9 \pm 1 \cdot 0$ & $10 \cdot 2 \pm 1 \cdot 1$ & $8 \cdot 7 \pm 1.2$ & \\
\hline
\end{tabular}

† Contrasts: a, normal versus reversed lighting regimen.

$\mathrm{b}$, 'lighting regimen $\times$ operation' interaction.

${ }^{*} P<0.05 ;{ }^{* *} P<0.01 ;{ }^{* * *} P<0.001$.

significant 'lighting regimen $\times$ operation' interactions recorded for all parameters mentioned above, except testicular weight and seminal vesicular fructose concentration. Similar trends shown by the mean values for ampullary weights and seminiferous tubule diameters were not statistically significant.

\section{Discussion}

This experiment showed that exposure of rams to a reversed annual lighting cycle altered the seasonal changes in some seminal characteristics; this result was confirmed by significant lighting regimen contrasts for many of the post-mortem testicular and accessory gland data. Significant effects of pinealectomy confirmed that the pineal gland was involved in photoperiodmediated influences on reproduction, a conclusion which had been reached earlier on the basis of plasma hormone data from these same rams (Barrell \& Lapwood, 1979c).

In the present experiment reversal of the lighting regimen altered ejaculate fructose content, as recorded by Jackson \& Williams (1973). However, this result was confined to sham-operated animals, indicating the requirement for an intact pineal gland for photoperiodic induction of this effect. Non-significant effects of lighting on seminal characteristics, particularly in the early stages of this study, may have arisen from the fact that artificial reversal of the lighting cycle was applied to rams which were experiencing a seasonal decrease in photoperiod, i.e. they were subjected to an abrupt decrease in photoperiod. Another 12 months of treatment might have produced a marked effect of contrasting lighting regimens on semen production. However, the present study was effective enough to induce significant accessory gland changes, suggesting that some alterations in semen quantity may already have occurred but were not of sufficient magnitude to be detected as significant.

When the rams were killed (in May) those under normal lighting should have just experienced their autumnal peak of reproductive activity and associated maximum reproductive organ weights (Lemay \& Corrivault, 1973), whereas the rams in the reversed lighting group were experiencing increasing daily photoperiods and would have been at low levels of reproductive 
potential. This hypothesis was well substantiated by some of the gonadal parameters evaluated at autopsy. Testicular weights and accessory gland data also reflected the levels of testosterone in the plasma of rams over the few weeks preceding the end of this experiment (Barrell \& Lapwood, 1979c).

Perhaps the most notable findings which arose from the accessory gland data were the number of significant results for the 'lighting regimen $\times$ operation' interactions which were interpreted as evidence for both antigonadotrophic and progonadotrophic roles for the pineal gland. An identical conclusion was reached by Hoffman \& Reiter (1966) who recorded a similar interaction for uterine weights in female hamsters. Lowered serum LH values caused by pinealectomy in male rats (van Bronswijk, Smith, van de Kar, Pevet \& Kappers, 1975) was further evidence for progonadotrophic activity of pineal origin. Collectively these findings established a dual role for the pineal gland, i.e. stimulatory or inhibitory to reproductive function, depending on the length of the daily photoperiod. Exactly how the pineal gland mediates these influences is unknown, but a number of substances with regulatory potential have been isolated from mammalian pineal glands. Such substances include the indoleamines, melatonin and serotonin (Reiter, 1973; Domański, Przekop, Skubiszewski \& Wolińska, 1975), arginine vasotocin (Pavel, Petrescu \& Vicoleanu, 1973), and gonadotrophin-releasing hormone (White et al., 1974; Duraiswami, Franchimont, Boucher \& Thieblot, 1976). It remains to be established if such compounds act necessarily at the hypothalamic or pituitary level, whether they modify the activity of reproductive glands directly, or whether their effects occur indirectly as a result of altered rates of secretions of hormones such as prolactin.

We thank Professor R. E. Munford for his advice and assistance with data analysis, $\mathrm{Mr} \mathrm{M}$. J. Birtles for histological processing, and Mr R. H. Telfer and Mr R. N. Ward for technical assistance.

\section{References}

Barrell, G.K. \& Lapwood, K.R. (1979a) Seasonality of semen production and plasma luteinizing hormone, testosterone and prolactin levels in Romney, Merino and Polled Dorset rams. Anim. Reprod. Sci. 1, 213-228.

Barrell, G.K. \& Lapwood, K.R. (1979b) Effects of modifying olfactory and pineal gland function on the seasonality of semen production and plasma luteinizing hormone, testosterone and prolactin levels in rams. Anim. Reprod. Sci. 1, 229-243.

Barrell, G.K. \& Lapwood, K.R. (1979c) Effects of pinealectomy on the secretion of luteinizing hormone, testosterone and prolactin in rams exposed to different lighting regimens. J. Endocr. 80, 397-405.

Cardinali, D.P., Nagle, C.A. \& Rosner, J.M. (1974) Changes in the pineal indole metabolism and plasma progesterone levels during the estrous cycle in ewes. Steroids Lipids Res. 5, 308-315.

Colas, G., Laszczka, A., Brice, G. \& Ortavant, R. (1972) Variations saisonnières de la production de sperme chez le bélier. Acta agr. \& silv.-Ser. zootech. 12, 315.

Domański, E., Przekop, F., Skubiszewski, B. \& Wolinska, E. (1975) The effect and site of action of indoleamines on the hypothalamic centres involved in the control of $\mathrm{LH}$ release and ovulation in sheep. Neuroendocrinology 17, 265-273.
Duraiswami, S., Franchimont, P., Boucher, D. \& Thieblot, M. (1976) Immunoreactive luteinizing hormone-releasing hormone (LH-RH) in the bovine pineal gland. Horm. Metab. Res. 8, 232-233.

Fisher, R.A. \& Yates, F. (1963) Statistical Tables for Biological, Agricultural and Medical Research, 6th edn. Oliver and Boyd, London.

Fowler, D.G. (1961) The effect of light on the semen characteristics of the Merino ram. Proc. Conf. Artif. Breed. Sheep in Aust., pp. 113-117. Ed. E. M. Roberts. University of New South Wales, Sydney.

Hoffman, R.A. \& Reiter, R.J. (1966) Responses of some endocrine organs of female hamsters to pinealectomy and light. Life Sci. 5, 1147-1151.

Jackson, G. \& Williams, H.LI. (1973) The effect of imposed light rhythms on semen production of Suffolk rams. J. agric. Sci., Camb. 81, 179-188.

Lemay, J.P. \& Corrivault, G.W. (1973) Variations saisonières de l'activité sexuelle chez le bélier. Naturaliste can. 100, 19-24.

Marshall, F.H.A. (1937) On the change over in the oestrous cycle in animals after transference across the equator, with further observations on the incidence of the breeding seasons and the factors controlling sexual periodicity. Proc. $R$. Soc. $B$ 122, 413-428.

Moule, G.R., Braden, A.W.H. \& Mattner, P.E. (1966) 
Effects of season, nutrition, and hormone treatment on the fructose content of ram semen. Aust. J. agric. Res. 17, 923-931.

New Zealand Nautical Almanac (1972) N.Z. Government Printer, Wellington.

Ortavant, R., Mauléon, P. \& Thibault, C. (1964) Photoperiodic control of gonadal and hypophyseal activity in domestic animals. Ann. N.Y. Acad. Sci. 117, 157-193.

Pavel, S., Petrescu, M. \& Vicoleanu, N. (1973) Evidence of central gonadotrophin inhibiting activity of arginine vasotocin in the female mouse. Neuroendocrinology 11, 370-374.

Reiter, R.J. (1973) Comparative physiology: pineal gland. A. Rev. Physiol. 35, 305-328.

Reiter, R.J. (1974) Circannual reproductive rhythms in mammals related to photoperiod and pineal function: a review. Chronobiologia 1, 365-395.
Roche, J.F. \& Dziuk, P.J. (1969) A technique for pinealectomy of the ewe. Am. J. vet. Res. 30, 20312035.

Roche, J.F., Karsch, F」., Foster, D.L., Takagi, S. \& Dziuk, P.J. (1970) Effect of pinealectomy on estrus, ovulation and luteinizing hormone in ewes. Biol. Reprod. 2, 251-254.

van Bronswijk, H., Smith., A.R., van de Kar, L., Pevet, P. \& Kappers, J.A. (1975) The effect of pinealectomy on serum levels of gonadotrophic hormones in the rat: a radioimmunoassay study. Acta endocr., Copenh., Suppl. 199, 317, Abstr.

White, W.F. Hedlund, M.T., Weber, G.F., Rippel, R.H., Johnson, E.S. \& Wilber, J.F. (1974) The pineal gland: a supplemental source of hypothalamicreleasing hormones. Endocrinology 94, 1422-1426.

Received 30 October 1978 